\title{
An Assessment of Data Mining Based CRM Techniques for Enhancing Profitability
}

\author{
Abdur Rahman ${ }^{a}$, M.N.A. Khan ${ }^{\text {a }}$ \\ ${ }^{a}$ Shaheed Zulfikar Ali Bhutto Institute of Science and Technology, Islamabad, Pakistan
}

\begin{abstract}
Customer Relationship Management (CRM) system is used to manage company relations with the existing and prospect customers. Data mining is used in organization for decision making and forecasting of prospective customers. We have studied recent literature related to use of data mining techniques for CRM. Based on review of the contemporary literature, we analyzed different data mining techniques employed in different types of business, corporate sectors and organizations. We illustrated a critical review table which provides the problem addressed, proposed techniques, significance, limitations and suggested possible improvements for each proposed techniques review during this study. The critical review of the data mining techniques which are being used for CRM is provided in this paper.
\end{abstract}

Index Terms: Business Intelligence, Customer Profitability, Customer Relationship Management, Data Mining, Machine Learning.

(C) 2017 Published by MECS Publisher. Selection and/or peer review under responsibility of the Research Association of Modern Education and Computer Science.

\section{Introduction}

Understanding the customer nature and characteristics is very important for the successful business growth. If we know what is the customer need or customer buying pattern then we can design market strategy to improve the business and services. Company correspondence with customers is an element which affects the customer loyalty. Data mining is used to extract the hidden knowledge and information from the data which assists decision maker to design better market strategy.

Business intelligence (BI) is a set of theories, methodologies, processes, architectures, and technologies that transform raw data into meaningful and useful information for business purposes. BI can handle large amounts of information to help identify and develop new opportunities. Availing new opportunities and implementing an effective business strategy can provide a competitive market advantage and long-term business stability.BI can save significant amounts of time by eliminating the need for extracting data through specialized tools and

\footnotetext{
* Corresponding author.
}

E-mail address: 
then committing the results back into the database. In addition, by having the data and the data model at the same location (such as Oracle database, Netezza), there is no need to export the model as a code.

$\mathrm{BI}$ is intended to deliver intelligence to the businesses and businesses use the output from BI systems to develop a strategy for their organizations. This can deliver enormous benefits, but, if the data is misunderstood, there are enormous risks as well. It is therefore essential to have a thorough understanding of the data to avoid these risks. A data model is a valuable tool which is used to help businesspeople and IT communicate effectively. The databases that are built to support BI must therefore contain the correct information in a format that the businesses can use. Corporate users typically see the output of BI systems as reports or digital dashboards, but underlying these systems are online analytical processing (OLAP) cubes. OLAP cubes preaggregate the results of queries, producing results in seconds when they might otherwise take hours. Each component of a BI system has different structures and requires different approaches for the data modeler. However, with meticulous use of modeling tools, we can avoid the risks of misinformation and extend the benefits of fully understanding the designs of our systems.

Business intelligence systems refer to a vast collection of tools and techniques that consist of expensive hardware solutions with state-of-the-art software. To produce intelligence, all BI systems require at least four specific components: data warehouses, ETL tools, OLAP techniques and data mining tools. BI system components are used to support a set of managerial decision-making actions. These actions emanate from disparate data sources and are described as: acquire(e.g. supported by the data warehousing component), gather (e.g. supported by the extract-transform-load component), analyze (e.g., supported by the use of online analytical products)and report (e.g., supported by the data-mining component).

Data clustering is a procedure in which we make cluster of entities ton based on their similar features. A good clustering technique will create high quality clusters with high intra-class similarity low inter-class similarity Quality of clustering depends on the similarity measure used and its implementation. Quality of a clustering process is measured by its ability to find out some or all of the unknown patterns. To creating a similarity clusters distance measured is used, which are as follow: Euclidean distance, Manhattan or taxicab distance, Mahalanobis distance, Inner product space, Hamming distance, Cosine Similarity Index, Minkowski distance. All distances are used to finds similarity in between different points but mostly Euclidian distance is used to measure objects for similarity attributes. Data Clustering is used in many different application areas; i.e. Data retrieval, Image analysis, Machine learning, web search engines, Pattern recognition, computational, economic, Libraries, insurances, city planning, and earthquakes studies.

There are so many data clustering algorithms to classified data into similar groups. Normally clustering algorithms are categorized into two groups as unsupervised linear clustering algorithm and unsupervised nonlinear clustering algorithm.

The area of application of big data includes banking, education, healthcare, government, manufacturers and retails. In the recent years, the concept of big data has been introduced to the healthcare system as a solution to a variety of healthcare related information system problems as health systems have grown increasingly complex and expensive. The healthcare sector deals with large volumes of electronic data related to patient services. As a result of rapid progress in digitizing medical records in recent times, healthcare organization and pharmaceutical companies have started collecting and storing more and more healthcare data in order to analyze it and obtain insights on how to solve problems related to variability in healthcare quality, skyrocketing healthcare cost, monitor, safety of healthcare systems etc. The main advantages of big data analysis is the cost reduction, faster, better decision making and to create new products and services for customers.

\section{Related Work}

Ahn et al. [1] develop classification model to support cross selling in a mobile telecom market using fusion data mining techniques. As mobile telecom industry is vastly growing and competition among mobile telecom operators has become more intense. Mobile industry is expanding their production across the world. They are using state of the art value added services (VAS) which generates more average revenue per user (ARPU).VAS 
is digital service and added extra features in the mobile phone network for example on line games, picture download, ringtones download, email, voucher and electronic transactions. It is also known as Mobile VAS. Cross selling is a CRM technique and mobile telecom operators used this technique to increase their profit and revenues. Ahn et al. [1] propose a customer classification technique which may be used for facilitating crossselling in a mobile telecom industry. Firstly, classification techniques like artificial neural networks (ANN), logistic regression (LR), and decision trees (DT) are applied one by one to predict the future purchase of products. Secondly, each model produces the result and then applied genetic algorithm on the combined results of all models and predict whether customer would purchase a new product. The framework is tested in a mobile telecom company in Korea. Therefore the model produced excellent results for cross-selling.

Bahari et al. [2] proposed an efficient CRM-data mining framework for the prediction of customer behavior. CRM-data mining framework is helpful to manage association between organizations and customers. The model improves the decision making process for retaining valued customers. Data mining techniques like classification are mostly used in CRM. Bahari et al. [2] compare two classification methods, Naïve Bayes and Neural Networks and results show that Neural Networks performance is better than Naïve Bayes. The authors applied model on bank marketing dataset that is standard UCI datasets.

Bose \& Chen [3] Explore business opportunities from mobile services data of customers using an intercluster analysis approach. The authors [3] utilize customer clustering technique to discover the customer behavior who assure to mobile services. The clustering is generally performed in services, revenue, usage and user categories attributes. In this study data mining techniques, K-means and Kohonen vector quantization (KVQ), are used to group customers based on the attributes. Then inter-cluster analysis is performed on the generated clusters and evaluated the scattering of customers among the dissimilar group of attributes. Customer transaction data was collected from mobile telecomm operator that is located in Hong Kong. There are 50,000 records in database for a period of one year and dataset range was $1^{\text {st }}$ Sep 2004 to $1^{\text {st }}$ Sep 2005. Data was partitioned in to four clusters. As a result this is found that K-means inclined to create clusters with a slighter variation in intra-cluster distribution and KVQ inclined toward creating clusters with slighter average intracluster distribution.

Chen et al. [4] discover recency, frequency and monetary (RFM) sequential patterns from customers' purchasing dataset. Mostly online retailers have developed online information systems and used to store large amount of transactions data of customers that is available on the internet. These systems automatically capture the customer purchasing records from the web browsing histories. Several data mining techniques have been designed to discover valuable customer information from the data for example cross-selling, customer profiling, web merchandising and e- catalog. Sequential pattern mining (SPM) is a beneficial data mining technique to determine customers' buying patterns over stipulated period of time. The authors [4] developed a new algorithm intended for produce RFM sequential patterns. RFM sequential patterns are derived from (RFM) notions. Using the RFM sequential patterns algorithm, authors [4] propose a pattern segmentation framework to produce imperative information which is helpful for decision making. Customer transactional dataset and synthetic datasets provided by a retail chain in Taiwan are used to assess the proposed algorithm. The results showed the benefits of using RFM sequential patterns in analyzing customers' purchasing data.

D'Haen et al. [5] predict the customer profitability during acquisition and find the optimal combination of data source and data mining technique. The customer acquisition process is a challenging task for retailing agents. There are models that assist them in choosing right customer to track. Two important elements of this process are profitability of customer and probability of customer once the lead is in fact a customer. The authors [5] focus on the profitability element. Web data and commercially accessible data are studied for predictive performance and measured the accuracy which is highest. Different data mining techniques are applied for predictive performance like decision trees, logistic regression and bagged decision trees. According to results bagged decision trees are constantly higher in precision and Web data is improved in predicting profitability than commercial data. If combined both then result is even better. The authors [5] defined a threshold to measure profitability. If sales volume is higher than in a certain value that was specified by the mail order oriented company then it is considered as profitable. 
Duchessi et al. [6] analyze ski resort's impact on sales and propose promotional and advertising strategies using decision tree. A ski resort is a resort developed for snowboarding, winter sports and skiing, Ski resort use different communication methods like public relations, advertising and sales promotion to communicate with their key market segment. Ski resorts are using a new digital communication channels for M-commerce, the proliferation of digital devices and E-commerce. The authors [6] propose decision tree models to profile the technologies and services. The technologies and services incorporate micro blogging services, resort websites and online coupon services. Ski resorts segments customer in two major categories i.e. millennial or Generation Y (less than or equal to 35) and non-millennial (greater than 35) and utilize promoting and advertising for them. Ski resorts greatly use Social Media Networks, Websites and Micro blogging technologies for promoting and advertising their services. According to result the technologies and services have great impact on resort sales. The impact is encouraging and mutually instant and persistent in nature.

Emtiyaz and Keyvanpour [7] analyze the customer behavior modeling by semi-supervised learning in Customer Relationship Management. Now companies are moving from product oriented to customer-centric organizations. It is generally believed that retaining existing customers is more profitable than attracting new ones. Customer data is rapidly growing, therefore, companies are facing problem to analyze valued customer for attracting and retaining. Data mining technologies extract hidden information and knowledge from large datasets stored in data warehouses or databases. The authors [7] applied semi-supervised learning technique to improve CRM processes and their efficiency. The proposed semi supervised method is helpful to predict the category of potential customers or unknown customers. The proposed technique is feed-forward neural network trained by a back propagation algorithm (multi-layer perceptron). Authors examined the proposed algorithm on Bank and Insurance datasets.

Griva et al. [8] analyze a data mining based framework to identify shopping patterns. The success of any business depends on the ability to understand its customers. Understanding the reasons buyers enter their preferred stores is playing an important role in achieving competitive advantage and retaining their market shares. Today, Business Analytics are helpful to explore the huge amount of data in order to gain customers insights and improve customer relationships. The authors propose the data mining based framework which could be used to discover patterns in customers' visits to a supermarket and identify their shopping missions. The application of proposed framework is applied in point of sale data of eight representative stores of a Greek retailer. It could be used to support several decisions in the retail domain and improve the relationships between retailers and consumers. This information is helpful to support several decisions in the retail domain and improve the relationships between retailers and consumers.

Hosseini et al. [9] analyze the customer loyalty in CRM using clustering and classification techniques. Data mining techniques are applied to extract hidden patterns that are inherited in the dataset. The authors used $\mathrm{K}$ means algorithm for clustering purpose. This study extends the traditional RFM (Recency, Frequency and Monetary) model by adding Weight (W) parameter thus renaming it as WRFM. The authors [9] classified the customer product loyalty for B2B concept joining WRFM with K-means and applied K-optimum (Davies Bouldin Index) for better cluster selection. CRM is a complete business and marketing strategy which integrates process, technology and all corporate events focused around the customer. Suppliers and service providers, B2B environment, need to understand the nature and characteristics of their customers. Since customer happiness and attraction are the core objective of any company. Therefore, customer loyalty or customer lifetime value (CLV) is calculated in terms of recency, frequency and monetary variables. Other literatures designed a model which calculates the distance between zero and centre of cluster and large number states the greatest customer loyalty. The similar method has been implemented in SAPCO in Iran. SAPCO is a leading car manufacturing company in Iran. Same approach can also be test in other service sectors and industries to assess their customer loyalty. The results show a remarkable proficiency to the corporate sector to evaluate their customer's loyalty and are helpful for designing better market strategy. Finally to classify the customers based on their loyalty, the authors used ANN and Decision Trees.

Khajvand et al. [10] estimate the customer lifetime value based on RFM analysis of customer purchase behavior. Customer significance is very important for any business. Generally companies are concentrating on 
customer profitability and loyalty to improve their market stake. Customer relationship management (CRM) is useful to arrange more targeted and adapted marketing. The authors [10] calculated customer lifetime value (CLV) for customer segmentation and applied in a Health and Beauty Company. CLV is calculated in two steps. Firstly, marketing analysis method based on RFM (Recency, Frequency, and Monetary) is used for customer segmentation. Secondly, count item parameter is added in RFM model. There is no improvement in clustering result after comparing these methods. Therefore weighted RFM (WRFM) method is applied for each segment and CLV is calculated using WRFM. Based on professional judgment of a sale and marketing department, relative importance (weight) of RFM attributes is determined. For this the Analytic Hierarchy Process (AHP) is used. Authors [10] applied K-means clustering method for customer segmentation in order to measure CLV for each segment. For obtaining optimum number of clusters DUNN index is used. CRISP (CRoss Industry Standard Process) methodology is applied for validation of this case study.

Liao et al. [11] analyze mining customer knowledge for tourism related new product development and customer relationship management. Tourism plays a major role in regional and national economic development. Tourism industry is rapidly growing and has become one of the fastest growing sectors of the world economy. Many companies in the world are developing and designing product for tourism industry and this is a growing source of domestic and foreign earnings. Customer relationship management (CRM) is helpful to design and improve market strategy that focused on the needs of customers. The authors [11] propose two methods: Cluster analysis for data mining and Apriori algorithm for association rules mining. The proposed model is implemented in a Phoenix Tours International company in Taiwan. Rules, knowledge and knowledge patterns are extracted from the dataset and propose solutions and suggestions based on the results to the tourism company for new product development and CRM.

Miguéis et al. [12] analyze lifestyle segmentation of customer using data mining technique. A decent relationship between customers and companies is a vital element of attractiveness and organization of loyalty relationships with customers is a focal tactical purpose. Therefore, companies are improving service levels and wishing to be at the top edge in order to certify a good business relationship with customers. The authors [12] extracted information from a large transaction database and propose a market segmentation technique for retailing based on customer's lifestyle. The authors used a variable clustering method to infer customers' lifestyle. The authors [12] identify typical shopping baskets based on products which are more repeatedly bought together. Lifestyle segment is assigned to customers based on their purchasing history. The propose model is implemented in European retailing company.

Shim et al. [13] develop CRM approach using association rules and sequential patterns for a small size online shopping mall. In 2002, dot-com bubble burst was established and contained several small-sized online shopping centers. Many of them become known in the market because they have good relations with customers and decent characteristics of online marketplace including significantly reduced menu cost for products/services and search costs and easily access services/products in the world. But some of the online shopping malls have not constantly succeeded and need to close them. Several of them have poor customer relationship management strategies and need to close them. The authors [13] analyze customer transactions data of the online shopping mall and propose sequential patterns and association rules. Firstly, authors [13] define the VIP customers based on recency, frequency and monetary (RFM) values. Formerly, they design a model which categories customers into non-VIP and VIP. The authors [13] used various data mining techniques such as logistic regression, bagging decision tree, artificial neural network and decision tree with each of these as a base classifier. Lastly, they identify patterns and rules for VIPs customer from the transactional data using association rules and sequential patterns and then design CRM strategies for the online shopping mall. References [15-58] reviewed different techniques in different domains and reported their critical evaluations.

\section{Critical Analysis}

A critical analysis of the literature reviewed in the previous section is summarized in the table below. 
Table 1. Critical Analysis Table.

\begin{tabular}{|c|c|c|c|c|c|c|}
\hline Sr \# & Reference & Problem Addressed & Proposed Technique & Benefits & $\begin{array}{l}\text { Limitations / } \\
\text { Weakness }\end{array}$ & $\begin{array}{l}\text { Suggested } \\
\text { Improvements }\end{array}$ \\
\hline 1 & $\begin{array}{l}\text { Ahn et al. } \\
(2011)\end{array}$ & $\begin{array}{l}\text { Develop } \\
\text { classification model } \\
\text { to support cross } \\
\text { selling in a mobile } \\
\text { telecom market } \\
\text { using fusion data } \\
\text { mining techniques }\end{array}$ & $\begin{array}{l}\text { Artificial Neural } \\
\text { Network, } \\
\text { Logistic Regression, } \\
\text { Decision Trees and } \\
\text { Genetic Algorithm. }\end{array}$ & $\begin{array}{l}\text { The authors propose } \\
\text { a new customer } \\
\text { classification model } \\
\text { for cross selling } \\
\text { which combines the } \\
\text { prediction results of } \\
\text { ANN, DT, LR and } \\
\text { using GA. }\end{array}$ & - & $\begin{array}{l}\text { Proposed model } \\
\text { can be tested in } \\
\text { other domain } \\
\text { like } \\
\text { Supermarket , } \\
\text { Medical , Banks } \\
\text { etc. }\end{array}$ \\
\hline 2 & $\begin{array}{l}\text { Bahari et al. } \\
\text { (2015) }\end{array}$ & $\begin{array}{l}\text { Proposed an } \\
\text { efficient CRM-data } \\
\text { mining framework } \\
\text { for the prediction of } \\
\text { customer behavior }\end{array}$ & $\begin{array}{l}\text { Naïve Bayes and Neural } \\
\text { Networks }\end{array}$ & $\begin{array}{l}\text { The authors applied } \\
\text { model on Bank } \\
\text { Marketing dataset } \\
\text { which is standard } \\
\text { UCI datasets. }\end{array}$ & $\begin{array}{l}\text { Synthesized } \\
\text { dataset is } \\
\text { used for } \\
\text { experiment. } \\
\text { Tests with } \\
\text { real dataset } \\
\text { are not } \\
\text { performed. }\end{array}$ & $\begin{array}{l}\text { Neuro fuzzy } \\
\text { classifiers can be } \\
\text { used for this } \\
\text { dataset. }\end{array}$ \\
\hline 3 & $\begin{array}{l}\text { Bose \& } \\
\text { Chen } \\
(2010)\end{array}$ & $\begin{array}{l}\text { Explore an inter- } \\
\text { cluster analysis } \\
\text { approach to explore } \\
\text { business } \\
\text { opportunities for } \\
\text { mobile service } \\
\text { customer data }\end{array}$ & $\begin{array}{l}\text { K-means and KVQ for } \\
\text { customer clustering. } \\
\text { CRISP methodology } \\
\text { Self-Organizing Maps } \\
\text { (SOM) }\end{array}$ & $\begin{array}{lr}\text { The } & \text { authors } \\
\text { discovered } \\
\text { attractive } \\
\text { information } \\
\text { customers of } \\
\text { instance for } \\
\text { discrepancy } \\
\text { between customer } \\
\text { habits of mobile } \\
\text { services, revenue } \\
\text { contributions and } \\
\text { subscriptions to } \\
\text { services. }\end{array}$ & - & $\begin{array}{l}\text { Other clustering } \\
\text { method can be } \\
\text { applied like } \\
\text { hierarchical } \\
\text { clustering and } \\
\text { fuzzy clustering. }\end{array}$ \\
\hline 4 & $\begin{array}{l}\text { Chen et al. } \\
(2009)\end{array}$ & $\begin{array}{l}\text { Discover } r \text { RFM } \\
\text { sequential patterns } \\
\text { from customer's } \\
\text { buying dataset }\end{array}$ & $\begin{array}{l}\text { RFM-Apriori algorithm } \\
\text { Apriori algorithm }\end{array}$ & $\begin{array}{l}\text { Customer } \\
\text { transactional dataset } \\
\text { and synthetic } \\
\text { datasets provided } \\
\text { by a retail chain in } \\
\text { Taiwan are used to } \\
\text { assess the proposed } \\
\text { algorithm }\end{array}$ & - & $\begin{array}{l}\text { CRISP } \\
\text { constraints are } \\
\text { used to discover } \\
\text { patterns. Fuzzy } \\
\text { constraints can } \\
\text { also be used for } \\
\text { pattern finding. }\end{array}$ \\
\hline 5 & $\begin{array}{l}\text { D'Haen et } \\
\text { al. (2013) }\end{array}$ & $\begin{array}{l}\text { Predict the customer } \\
\text { profitability during } \\
\text { acquisition and find } \\
\text { the optimal } \\
\text { combination of data } \\
\text { source and data } \\
\text { mining technique }\end{array}$ & $\begin{array}{l}\text { Bagged Decision Trees } \\
\text { Logistic Regression } \\
\text { Decision Trees }\end{array}$ & $\begin{array}{l}\text { The application of } \\
\text { proposed model is } \\
\text { implemented in } \\
\text { German mail order } \\
\text { oriented company. }\end{array}$ & $\begin{array}{l}\text { The scope of } \\
\text { the study is } \\
\text { limited to } \\
\text { B2B market } \\
\text { only. Budget } \\
\text { constraints to } \\
\text { purchased } \\
\text { data from } \\
\text { specialized } \\
\text { vendor. Data } \\
\text { Quality } \\
\text { Issues }\end{array}$ & $\begin{array}{l}\text { Proposed model } \\
\text { can be tested on } \\
\text { Web data. }\end{array}$ \\
\hline
\end{tabular}




\begin{tabular}{|c|c|c|c|c|c|c|}
\hline 6 & $\begin{array}{l}\text { Duchessi et } \\
\text { al. (2013) }\end{array}$ & $\begin{array}{l}\text { Analyze decision } \\
\text { tree models for } \\
\text { profiling ski resorts' } \\
\text { promotional and } \\
\text { advertising } \\
\text { strategies and the } \\
\text { impact on sales. }\end{array}$ & 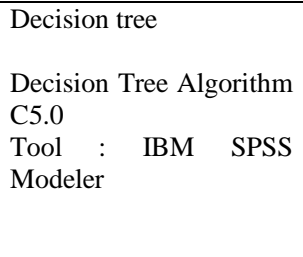 & $\begin{array}{lr}\text { Ski resorts } & \text { greatly } \\
\text { use Social Media } \\
\text { Networks, Websites } \\
\text { and Microblogging } \\
\text { technologies for } \\
\text { promoting and } \\
\text { advertising their } \\
\text { services }\end{array}$ & - & $\begin{array}{l}\text { Customer } \\
\text { segmentation can } \\
\text { be performed on } \\
\text { other variables } \\
\text { like geographic, } \\
\text { customer value } \\
\text { and } \\
\text { psychographic }\end{array}$ \\
\hline 7 & $\begin{array}{l}\text { Emtiyaz } \\
\text { and } \\
\text { Keyvanpour } \\
\text { (2012) }\end{array}$ & $\begin{array}{l}\text { Analyze the } \\
\text { customer behaviour } \\
\text { modelling by semi- } \\
\text { supervised learning } \\
\text { in Customer } \\
\text { Relationship } \\
\text { Management } \\
\text { Thiess datasets } \\
\text { representing CRM } \\
\text { problems have been } \\
\text { used in the } \\
\text { experiment. } \\
\text { Thiess is the world's } \\
\text { largest contract } \\
\text { miner with } 24 \text { mines } \\
\text { across six countries }\end{array}$ & $\begin{array}{l}\text { Labelled and Unlabeled } \\
\text { data stored in Data } \\
\text { Warehouse } \\
\text { Trained Neural Network } \\
\text { using Labelled data } \\
\text { Classified Unlabeled } \\
\text { data based on Labelled } \\
\text { data } \\
\text { Calculated Confidence } \\
\text { and assigned Labelled } \\
\text { Compared performance } \\
\text { of Bank and Insurance } \\
\text { data using Rapid Miner } \\
\text { tool like Proposed } \\
\text { Algorithm, Neural Net, } \\
\text { SVM, KNN and Naïve } \\
\text { Bayes. }\end{array}$ & $\begin{array}{l}\text { Modified Neural } \\
\text { Net Operator codes } \\
\text { of Rapid Miner to } \\
\text { improve the results. } \\
\text { By changing the } \\
\text { formula from } \\
\text { ( Number of } \\
\text { Attributes } \\
\text { Number of Classes) } \\
\text { / 2) + 1 } \\
\text { to } \\
\text { (Number } \\
\text { Attributes } \\
\text { Number of Classes) } \\
\text { / } 4\end{array}$ & - & $\begin{array}{l}\text { Other } \\
\text { classification } \\
\text { methods can be } \\
\text { applied like } \\
\text { Fuzzy Neural } \\
\text { Network, etc. }\end{array}$ \\
\hline 8 & $\begin{array}{l}\text { Griva et al. } \\
\text { (2014) }\end{array}$ & $\begin{array}{lrr}\text { Analyze } & \text { a } & \text { data } \\
\text { mining } & \text { based } \\
\text { framework } & \text { to } \\
\text { identify } & \text { shopping } \\
\text { patterns. } & \end{array}$ & $\begin{array}{l}\text { CRISP-DM } \\
\text { K-means }\end{array}$ & $\begin{array}{l}\text { The application of } \\
\text { proposed } \\
\text { framework is } \\
\text { applied in point of } \\
\text { sale data of eight } \\
\text { representative stores } \\
\text { of a Greek retailer }\end{array}$ & - & $\begin{array}{l}\text { Other data } \\
\text { mining } \\
\text { techniques can } \\
\text { be applied like } \\
\text { association rule } \\
\text { mining, apriori } \\
\text { algorithm, } \\
\text { nearest } \\
\text { neighbour } \\
\text { algorithm etc. }\end{array}$ \\
\hline 9 & $\begin{array}{l}\text { Hosseini et } \\
\text { al. } \\
(2010)\end{array}$ & $\begin{array}{lr}\text { Analyze } & \text { the } \\
\text { customer loyalty in } \\
\text { CRM } & \text { using } \\
\text { clustering } & \text { and } \\
\text { classification } & \\
\text { techniques } & \end{array}$ & $\begin{array}{l}\text { K-means for clustering } \\
\text { Artificial Neural } \\
\text { Network } \\
\text { Decision Tree }\end{array}$ & $\begin{array}{l}\text { The application of } \\
\text { proposed model is } \\
\text { implemented in a } \\
\text { car manufacturing } \\
\text { company in Iran. }\end{array}$ & $\begin{array}{l}\text { The scope of } \\
\text { the study is } \\
\text { limited to } \\
\text { B2B market }\end{array}$ & $\begin{array}{l}\text { Instead of K- } \\
\text { means, k-medoid } \\
\text { can be used to } \\
\text { assess } \\
\text { performance } \\
\text { enhancement for } \\
\text { customer } \\
\text { clusters. }\end{array}$ \\
\hline 10 & $\begin{array}{l}\text { Khajvand et } \\
\text { al. } \\
(2011)\end{array}$ & $\begin{array}{l}\text { Estimate the } \\
\text { customer lifetime } \\
\text { value based on RFM } \\
\text { analysis of customer } \\
\text { purchase behavior }\end{array}$ & $\begin{array}{l}\text { K-means } \\
\text { DUNN index } \\
\text { CRISP methodology } \\
\text { AHP method for } \\
\text { evaluating usefulness of } \\
\text { RFM variables. }\end{array}$ & $\begin{array}{l}\text { The application of } \\
\text { proposed model is } \\
\text { implemented in a } \\
\text { health and Beauty } \\
\text { company in Iran. }\end{array}$ & $\begin{array}{l}\text { The research } \\
\text { has only been } \\
\text { validated } \\
\text { through a } \\
\text { case study } \\
\text { and no proper } \\
\text { deployment is } \\
\text { carried out. }\end{array}$ & $\begin{array}{l}\text { Deployment of } \\
\text { proposed model } \\
\text { in a firm could } \\
\text { be useful to } \\
\text { measure its } \\
\text { effectiveness. }\end{array}$ \\
\hline
\end{tabular}




\begin{tabular}{|c|c|c|c|c|c|c|}
\hline 11 & $\begin{array}{l}\text { Liao et al. } \\
(2010)\end{array}$ & $\begin{array}{lr}\text { Analyze mining } \\
\text { customer knowledge } \\
\text { for tourism related } \\
\text { new product } \\
\text { development and } \\
\text { customer r } \\
\text { relationship } \\
\text { management }\end{array}$ & $\begin{array}{l}\text { Cluster analysis based on } \\
\text { patterns } \\
\begin{array}{l}\text { Apriori Algorithm for } \\
\text { association rules }\end{array}\end{array}$ & $\begin{array}{l}\text { The proposed } \\
\text { model is } \\
\text { implemented in a } \\
\text { Phoenix Tours } \\
\text { International } \\
\text { company in Taiwan }\end{array}$ & - & $\begin{array}{l}\text { Other clustering } \\
\text { techniques can } \\
\text { be implemented } \\
\text { like hierarchal } \\
\text { clustering etc. }\end{array}$ \\
\hline 12 & $\begin{array}{l}\text { Miguéis et } \\
\text { al. (2012) }\end{array}$ & $\begin{array}{l}\text { Analyze customer } \\
\text { data mining for } \\
\text { lifestyle } \\
\text { segmentation }\end{array}$ & $\begin{array}{l}\begin{array}{l}\text { Variable } \\
\text { method } \\
\text { correlation } \\
\text { variables) }\end{array} \\
\text { (measured } \\
\text { between }\end{array}$ & $\begin{array}{l}\text { The application of } \\
\text { proposed model is } \\
\text { implemented in an } \\
\text { European retailing } \\
\text { company. }\end{array}$ & - & $\begin{array}{l}\text { Other clustering } \\
\text { method like K- } \\
\text { means can be } \\
\text { used for this } \\
\text { dataset. }\end{array}$ \\
\hline 13 & $\begin{array}{l}\text { Shim et al. } \\
(2012)\end{array}$ & $\begin{array}{lr}\text { develop } & \text { CRM } \\
\text { strategies for a } \\
\text { small-sized online } \\
\text { shopping mall based } \\
\text { on association rules } \\
\text { and sequential } \\
\text { patterns }\end{array}$ & $\begin{array}{l}\text { Decision Trees } \\
\text { Artificial Neural } \\
\text { Network } \\
\text { Logistic Regression } \\
\text { Bagged Decision Trees }\end{array}$ & $\begin{array}{l}\text { The proposed } \\
\text { model is } \\
\text { implemented in dot- } \\
\text { com bubble burst in } \\
\text { Korea. }\end{array}$ & $\begin{array}{l}\text { Worked only } \\
\text { VIP customer } \\
\text { dataset which } \\
\text { are ordinarily } \\
\text { small in size }\end{array}$ & $\begin{array}{l}\text { The technique } \\
\text { was applied only } \\
\text { for VIP } \\
\text { customers and it } \\
\text { can be tested for } \\
\text { non-VIP } \\
\text { customer to } \\
\text { check to } \\
\text { effectiveness to } \\
\text { determine real } \\
\text { benefits and } \\
\text { increase the } \\
\text { revenue and } \\
\text { customer base. }\end{array}$ \\
\hline
\end{tabular}

\section{Conclusion and Future Work}

Data mining is used in organization for decision making and forecasting of prospective customers. We have studied recent literature related to use of data mining techniques for CRM. Based on review of the contemporary literature, we analyzed different data mining techniques employed in different types of business, corporate sectors and organizations. We draw a critical review table which provides the problem addressed, proposed techniques, significance, limitations and suggested possible improvements for each proposed techniques review during this study. The critical review of the data mining techniques which are being used for CRM is provided in this paper.

As a future work, we will develop a framework which will be used for enhancing profitability based on data mining techniques. In the existing literature, we have identified various challenges that are being faced during effective use of CRM systems. We have also identified the possible room for improvement in various data mining techniques currently being used in CRM system. Based on this, we intend to use CRISP-DM technique in the future to explore its effectiveness in the CRM system in order to make CRM system more efficient and robust.

\section{References}

[1] H. Ahn, J. J. Ahn, K. J. Oh, and D. H. Kim, "Facilitating cross-selling in a mobile telecom market to develop customer classification model based on hybrid data mining techniques," Expert Systems with Applications, 38(5), 5005-5012, 2011.

[2] T. F. Bahari, and M. S. Elayidom, "An Efficient CRM-Data Mining Framework for the Prediction of 
Customer Behaviour," Procedia Computer Science, 46, 725-731, 2015.

[3] I. Bose, and X. Chen, "Exploring business opportunities from mobile services data of customers: An intercluster analysis approach," Electronic Commerce Research and Applications, 9(3), 197-208, 2010.

[4] Y. L. Chen, M. H. Kuo, S. Y. Wu, and K. Tang, "Discovering recency, frequency, and monetary (RFM) sequential patterns from customers' purchasing data," Electronic Commerce Research and Applications, $8(5), 241-251,2009$.

[5] J. D'Haen, D. Van den Poel, and D. Thorleuchter, "Predicting customer profitability during acquisition: Finding the optimal combination of data source and data mining technique," Expert systems with applications, 40(6), 2007-2012, 2013.

[6] P. Duchessi, and E. J. Lauría, "Decision tree models for profiling ski resorts' promotional and advertising strategies and the impact on sales," Expert Systems with Applications, 40(15), 5822-5829, 2013.

[7] S. Emtiyaz, and M. Keyvanpour, "Customers behavior modeling by semi-supervised learning in customer relationship management," arXiv preprint arXiv:1201.1670, 2012.

[8] A. Griva, C. Bardaki, S. Panagiotis, and D. Papakiriakopoulos, "A Data Mining Based Framework to Identify Shopping Missions," 2014.

[9] S. M. S. Hosseini, A. Maleki, and M. R. Gholamian, "Cluster analysis using data mining approach to develop CRM methodology to assess the customer loyalty," Expert Systems with Applications, 37(7), 5259-5264, 2010.

[10] M. Khajvand, K. Zolfaghar, S. Ashoori, and S. Alizadeh, "Estimating customer lifetime value based on RFM analysis of customer purchase behavior: Case study," Procedia Computer Science, 3, 57-63, 2011.

[11] S. H. Liao, Y. J. Chen, and M. Y. Deng, "Mining customer knowledge for tourism new product development and customer relationship management," Expert Systems with Applications, 37(6), 42124223, 2010.

[12] V. L. Miguéis, A. S. Camanho, and J. F. e Cunha, "Customer data mining for lifestyle segmentation," Expert Systems with Applications, 39(10), 9359-9366, 2012.

[13] B. Shim, K. Choi, and Y. Suh, "CRM strategies for a small-sized online shopping mall based on association rules and sequential patterns," Expert Systems with Applications, 39(9), 7736-7742, 2012.

[14] C. Pete, C. Julian, K . Randy, K. Thomas, R. Thomas, S. Colin, and W. Rüdiger "CRISP-DM," NCR, SPSS, DaimlerChrysler. USA, 2000, pp.1-76.

[15] S. Iqbal, M. Khalid, M. N. A. Khan, "A Distinctive Suite of Performance Metrics for Software Design", International Journal of Software Engineering \& Its Applications, vol. 7, no. 5, (2013).

[16] S. Iqbal and M. N. A. Khan, "Yet another Set of Requirement Metrics for Software Projects", International Journal of Software Engineering \& Its Applications, vol. 6, no. 1, (2012).

[17] M. Faizan, S. Ulhaq, M. N. A. Khan, "Defect Prevention and Process Improvement Methodology for Outsourced Software Projects", Middle-East Journal of Scientific Research, vol. 19, no. 5, (2014), pp. 674-682.

[18] M. Faizan, M. N.A. Khan, S. Ulhaq, "Contemporary Trends in Defect Prevention”, A Survey Report. International Journal of Modern Education \& Computer Science, vol. 4, no. 3, (2012).

[19] K. Khan, A. Khan, M. Aamir and M. N. A. Khan, "Quality Assurance Assessment in Global Software Development” World Applied Sciences Journal, vol. 24, no. 11, (2013).

[20] M. Amir, K. Khan, A. Khan, M. N. A. Khan, "An Appraisal of Agile Software Development Process", International Journal of Advanced Science \& Technology, vol. 58, (2013).

[21] M. Khan and M. N. A. Khan, "Exploring Query Optimization Techniques in Relational Databases", International Journal of Database Theory \& Application, vol. 6, no. 3, (2013).

[22] M. N. A. Khan, M. Khalid and S. UlHaq, "Review of Requirements Management Issues in Software Development", International Journal of Modern Education \& Computer Science, vol. 5, no. (1), (2013).

[23] M. Umar and M. N. A. Khan, "A Framework to Separate NonFunctional Requirements for System Maintainability", Kuwait Journal of Science \& Engineering, vol. 39, no. 1 B, (2012), pp. 211- 231.

[24] M. Umar and M. N. A. Khan, Analyzing Non-Functional Requirements (NFRs) for software development. 
In IEEE 2nd International Conference on Software Engineering and Service Science (ICSESS), (2011), pp. 675-678).

[25] M. N. A. Khan, C. R. Chatwin and R. C. Young, "A framework for post-event timeline reconstruction using neural networks", digital investigation, vol. 4, no. 3, (2007), pp. 146-157.

[26] M. N. A. Khan, C. R. Chatwin and R. C. Young, "Extracting Evidence from File system Activity using Bayesian Networks", International journal of Forensic computer science, vol. 1, (2007), pp. 50-63.

[27] M. N. A. Khan, "Performance analysis of Bayesian networks and neural networks in classification of file system activities", Computers \& Security, vol. 31, no. 4, (2012), pp. 391-401.

[28] M. Rafique and M. N. A. Khan, "Exploring Static and Live Digital Forensics: Methods, Practices and Tools", International Journal of Scientific \& Engineering Research, vol. 4, no. 10, (2013), pp. 1048-1056.

[29] M. S. Bashir and M. N. A. Khan, "Triage in Live Digital Forensic Analysis", International journal of Forensic Computer Science, vol. 1, (2013), pp. 35-44.

[30] A. Sarwar and M. N. A. Khan, "A Review of Trust Aspects in Cloud Computing Security", International Journal of Cloud Computing and Services Science (IJCLOSER), vol. 2, no. 2, (2013), pp. 116-122.

[31] A. H. Gondal and M. N. A. Khan, "A review of fully automated techniques for brain tumor detection from MR images", International Journal of Modern Education and Computer Science (IJMECS), vol. 5, no. 2, (2013), pp. 55.

[32] A. Zia and M. N. A. Khan, "Identifying key challenges in performance issues in cloud computing", International Journal of Modern Education and Computer Science (IJMECS), vol. 4, no. 10, (2012), pp. 59.

[33] K. U. Rehman and M. N. A. Khan, "The Foremost Guidelines for Achieving Higher Ranking in Search Results through Search Engine Optimization”, International Journal of Advanced Science and Technology, vol. 52, (2013), pp. 101-110.

[34] M. Khan and M. N. A. Khan, "Exploring query optimization techniques in relational databases", International Journal of Database Theory \& Application, vol. 6, no. 3, (2013).

[35] R. Shehzad, M. N. KHAN and M. Naeem, "Integrating knowledge management with business intelligence processes for enhanced organizational learning", International Journal of Software Engineering and Its Applications, vol. 7, no. 2, (2013), pp. 83-91.

[36] S. U. Haq, M. Raza, A. Zia and M. N. A. Khan, "Issues in global software development: A critical review", Journal of Software Engineering and Applications, 4(10), 590, 2015.

[37] A. S. Shah, M. N. A. Khan and A. Shah. An appraisal of off-line signature verification techniques. International Journal of Modern Education and Computer Science, 7(4), 67-75, 2015.

[38] A. Zia and M. N. A. Khan, "A Scheme to Reduce Response Time in Cloud Computing Environment", International Journal of Modern Education and Computer Science (IJMECS), vol. 5, no. 6, (2013), pp. 56.

[39] M. Tariq and M. N. A. Khan, "The Context of Global Software Development: Challenges, Best Practices and Benefits", Information Management \& Business Review, vol. 3, no. 4, (2011).

[40] A. Shahzad, M. Hussain and M. N. A. Khan, "Protecting from Zero-Day Malware Attacks", Middle-East Journal of Scientific Research, vol. 17, no. 4, (2013), pp. 455-464.

[41] A. A. Khan and M. Khan, "Internet content regulation framework", International Journal of U-\& EService, Science \& Technology, vol. 4, no. 3, (2011).

[42] K. Ullah and M. N. A. Khan, "Security and Privacy Issues in Cloud Computing Environment: A Survey Paper", International Journal of Grid and Distributed Computing, vol. 7, no. 2, (2014), pp. 89-98.

[43] A. A. Abbasi, M. N. A. Khan and S. A. Khan, "A Critical Survey of Iris Based Recognition Systems", Middle-East Journal of Scientific Research, vol. 15, no. 5, (2013), pp. 663- 668.

[44] M. N. A. Khan, S. A. Qureshi and N. Riaz, "Gender classification with decision trees", Int. J. Signal Process. Image Process. Patt. Recog, vol. 6, (2013), pp. 165-176.

[45] S. S. Ali and M. N. A. Khan, "ICT Infrastructure Framework for Microfinance Institutions and Banks in Pakistan: An Optimized Approach”, International Journal of Online Marketing (IJOM), vol. 3, no. 2, 2013, pp. 75-86. 
[46] A. Mahmood, M. Ibrahim and M. N. A. Khan, "Service Composition in the Context of Service Oriented Architecture", Middle East Journal of Scientific Research, vol. 15, no. 11, 2013.

[47] M. A. Masood and M. N. A. Khan, "Clustering Techniques in Bioinformatics", I. J. Modern Education and Computer Science, vol. 1, 2015, pp. 38-46.

[48] T. Ur Rehman, M. N. A. Khan, N. Riaz. Analysis of Requirement Engineering Processes, Tools/Techniques and Methodologies. International Journal of Information Technology and Computer Science (IJITCS), 5(3), 40, 2013.

[49] R. Ahmed, M. N. A. Khan. An Analytical Review of Stereovision Techniques to Reconstruct 3D Coordinates. International Journal of Information Technology and Computer Science (IJITCS), 5(7), 80. 2013.

[50] M.F. Malik, M. N. A. Khan. An Analysis of Performance Testing in Distributed Software Applications. International Journal of Modern Education \& Computer Science, 8(7), 2016.

[51] R. Naz, M. N. A. Khan, M. Aamir. Scrum-Based Methodology for Product Maintenance and Support. IJEM-International Journal of Engineering and Manufacturing (IJEM), 6(1), 10, 2016.

[52] S. Rahman, M. N. A. Khan. Digital Forensics through Application Behavior Analysis. International Journal of Modern Education \& Computer Science, 2016.

[53] S. Shafqat, M. N. A. Khan, N. Riaz, K. Khan. Identity Matrix: Architecture Framework for Trusted Cloud Computing through Cloud Intellect. Journal of Internet Technology, 17(4), 2016.

[54] G. Ahmed, M. N. A. Khan, M.S. Bashir. A Linux-based IDPS using Snort. Computer Fraud \& Security, 2015(8), 13-18, 2015.

[55] M. Rafique, M. N. A. Khan. Profiling software applications for forensic analysis. Computer Fraud \& Security, 2015(6), 13-18, 2015.

[56] M. Khan, M. Akram, N. Riaz. A comparative analysis of software protection schemes. Int. Arab J. Inf. Technol., 12(3), 286-295, 2015.

[57] G. Ahmed, M. Hussain, M. N. A. Khan. Characterizing Strengths of Snort-based IDPS. Research Journal of Recent Sciences. 2014.

[58] A., Abbasi, M. Khan. Iris-Pupil Thickness Based Method for Determining Age Group of a Person. International Arab Journal of Information Technology, No.6, November 2016.

\section{Authors' Profiles}

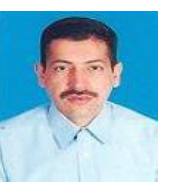

Abdur Rahman obtained MS degree in Software Engineering at Shaheed Zulfikar Ali Bhutto Institute of Science and Technology, Islamabad. His research areas include software engineering and data mining techniques.

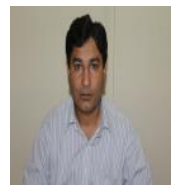

M.N.A. Khan obtained D.Phil. degree from the University of Sussex. His research interests are in the fields of software engineering, cyber administration, digital forensic analysis and machine learning techniques.

How to cite this paper: Abdur Rahman, M.N.A. Khan,"An Assessment of Data Mining Based CRM Techniques for Enhancing Profitability", International Journal of Education and Management Engineering(IJEME), Vol.7, No.2, pp.30-40, 2017.DOI: 10.5815/ijeme.2017.02.04 